\title{
PERANAN SUPERVISI KEPALA SEKOLAH DALAM MENINGKATKAN KINERJA GURU DI SMP TAWAKKAL DENPASARTAHUN PELAJARAN 2019/2020
}

\author{
Didik Budi Wibowo ${ }^{1}$, Achmad Qasim $^{2}$, Tauhid Hidayat, ${ }^{3}$ \\ ${ }^{1}$ Program Studi Manajemen Pendidikan Islam, Sekolah Tinggi Agama Islam Denpasar Bali, \\ Denpasar, Indonesia \\ ${ }^{2,3}$ Program Studi Pendidikan Agama Islam, Sekolah Tinggi Agama Islam Denpasar Bali, \\ Denpasar, Indonesia
}

e-mail: \{wiiibowo29@gmail.com, staidenpasar@gmail.com, stauhid72@gmail.com $\}$

\begin{abstract}
ABSTRAK
Peningkatan kinerja guru dipengaruhi oleh peran supervisi Kepala Sekolah antara lain memperbaiki mutu mengajar guru, membina pertumbuhan profesi guru, peningkatkan mutu pengetahuan dan ketrampilan guru, pemberian bimbingan serta pemilihan dan penggunaan metode mengajar seperti alat-alat pelajaran, prosedur dan tehnik evaluasi pengajaran.Adapun fokus penelitian dalam penelitian ini adalah: 1) Bagaimana Peran Supervisi Kepala Sekolah dalam meningkatkan Kinerja Guru di SMP Tawakkal Denpasar Tahun Pelajaran 2019/2020?, 2) Apa hambatan dan solosinya dalam meningkatkan kinerja guru di SMP Tawakkal Denpasar Tahun Pelajaran 2019/2020?Sedangkan tujuan penelitian ini adalah untuk mengetahui: 1) Peran Supervisi Kepala Sekolah Dalam Meningkatkan Kinerja Guru Di SMP Tawakkal Denpasar Tahun Pelajaran 2019/2020, 2) Hambatan Dan Solosi Dalam Meningkatkan Kinerja Guru Di SMP Tawakkal Denpasar Tahun Pelajaran 2019/2020. Penelitian ini merupakan penelitian lapangan yang betujuan mempelajari secara intensif tentang latar belakang keadaan sekarang, interaksi sosial atau individu, kelompok, lembaga dan masyarakat.Adapun jenis penelitian ini menggunakan pendekatan kualitatif yang bersifat deskriptif. Narasumber dalam penelitian ini adalah kepala sekolah, wakil kepala sekolah, pegawai tata usaha, guru dan komite SMP Tawakkal Denpasar yang berjumlah 5 orang. Teknik pengumpulan data yang digunakan adalah wawancara, observasi, dan dokumentasi. Analisis data dilakukan secara interaktif yaitu mulai dari reduksi data, penyajian data, dan penarikan kesimpulan.Berdasarkan hasil penelitian ditemukan: 1) Peran supervisi kepala sekolah dalam meningkatkan kinerja guru di SMP Tawakkal Denpasar sudah berjalan dengan baik 2) Hambatan dan solusi dalam meningkatkan kinerja guru sudah sesuai dengan standar kinerja guru yang berlaku.
\end{abstract}

\section{.Kata kunci: Supervisi Meningkatkan Kinerja Guru}

\begin{abstract}
This research was motivated by all teachers in SMP Tawakkal Denpasarhave met academic qualification standards. However, it seems that the teacher's academic qualifications have not been able to maximize the student's learning achievement. This is evidenced by a decrease in learning achievement. The purpose of this research is to know qualifications teachers in improving student learning achievement and the inhibitory and supporting factors faced by teachers in improving student learning achievement at SMP Tawakkal DenpasarYears lesson 2019/2020. This study uses a qualitative approach, with a qualitative interpretive method. Determination of the informant was done by purposive sampling. The data collection techniques was by observation, interviews, and documentation. The results of the study revealed that, the role of teacher qualifications is improving learning achievement is determined by academic and non-academic qualifications, learning planning qualifications, learning process qualifications, personality qualifications, and learning process results through evaluation. While the supporting factors of learning achievement internally are student intelligence, internal motivation, as well as interests and talents. The external support factors are parental motivation, adequate facilities, out-of-school tutoring, and teacher rewarding. The inhibitory factor of learning achievement consists of internal factors, namely lack of motivation and interest in learning. Meanwhile, the external factor is the lack of attention from parents, students not taking additional lessons outside of school, and less supportive facilities.
\end{abstract}

Keywords: : Supervision to Improve Teacher Performance ement 


\section{PENDAHULUAN}

Perkembangan ilmu pengetahuan dan teknologi (IPTEK) mengharuskan orang untuk belajar terus. Lebih lebih kepala sekolah yang mempunyai tugas sebagai supervisor harus memiliki kemampuan yang cukup agar dapat mengatasi kesulitan guru dalam mengajar.

Bimbingan dan pengawasan yang dilakukan kepala sekolah sebagai supervisor terhadap guru adalah sebagai usaha yang memberikan kesempatan bagi para guru untuk berkembang secara professional, Sehingga mereka lebih maju lagi dalam melaksanakan tugas pokoknya

Mengingat pentingnya pengawasan dan bimbingan bagi guru, maka kepala sekolah harus senantiasa meningkatkan dan menyegarkan pengetahuannya beberapa tingkat lebih baik di banding guru, karena jika kemampuan kepala sekolah itu sama bahkan dibawah guru kualitasnya, maka tugas bimbingan dan pemberi bantuan bagi guru tidak begitu berarti. Kepala sekolah sebagi supervisor dalam melakukan tugasnya harus mengetahui secara jelas apa-apa yang harus disupervisi dan bagaimana tekniknya.

"Secara terminologis, supervisi sering diartikan sebagai serangkaian usaha bantuan kepada guru. Terutama bantuan yang berwujud layanan professional yang dilakukan oleh kepala sekolah dan pengawas serta supervisor lainnya untuk meningkatkan proses dan hasil belajar".

Supervisi pendidikan didefinisikan sebagai proses pemberian layanan bantuan profesional kepada guru untuk meningkatkan kemampuannya dalam melaksanakan tugastugas pengelolaan proses pembelajaran secara efektif dan efisien. Dengan adanya pelaksanaan supervisi oleh kepala sekolah diharapkan memberi dampak terhadap terbentuknya sikap professional guru. Sikap professional guru merupakan hal yang amat penting dalam memelihara dan meningkatkan profesionalitas guru, karena selalu berpengaruh pada perilaku dan aktivitas keseharian guru. "Perilaku profesional akan lebih diwujudkan dalam diri guru apabila institusi tempat ia bekerja memberi perhatian lebih banyak pada

${ }^{1}$ Ali Imron, Supervisi Pembelajaran Tingkat satuan Pendidikan, (Jakarta: PT. Bumi Aksara, 2012) Cet. Ke 2, h. 8. pembinaan, pembentukan, dan pengembangan sikap profesional". ${ }^{2}$

Pentingnya peran kepala sekolah sebagai supervisor pendidikan memiliki tanggung jawab yang besar di sisi Allah, sesuai dengan firman Allah dalam surah Al-Infithar yaitu:

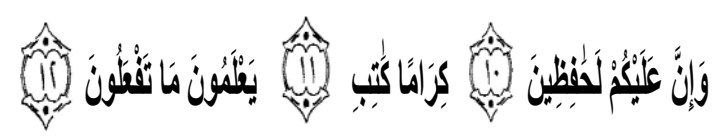

Artinya: "Padahal sesungguhnya bagi kamu ada (malaikat-malaikat) yang mengawasi (pekerjaanmu). Yang mulia (di sisi Allah) dan mencatat (pekerjaan-pekerjaan itu). Mereka mengetahui apa yang kamu kerjakan. (QS. AlInfithar: 10-12) ${ }^{3}$

Kegiatan supervisi kepala sekolah berpengaruh secara psikologis terhadap kinerja guru. Keberhasilan sekolah adalah keberhasilan dalam bertangung jawab dan menjalankan tugasnya sebagai pemimpin suatu organisasi. Sekolah adalah suatu organisasi yang kompleks oleh karena itu kepala sekolah harus mampu mengarahkan dan mengkoordinasi semua kegiatan pendidikan terutama terhadap tenaga pendidik yaitu kepada para guru sebagai pengajar yang harus menguasai ilmu dan keterampilan yang sesuai dengan sepesifikasi keahlian bidang studinya dan diharapkan mampu mempersiapkan, melaksanakan pembelajaran dengan baik

Keberhasilan proses pembelajaran di sekolah banyak dipengaruhi faktor kepala sekolah, guru dan siswa. Oleh karena itu kemampuan dan kualitas guru dalam melaksanakan kegiatan pembelajaran perlu ditingkatkan dengan pengawasan dan bimbingan dari kepala sekolah sebagai supervisor pendidikan. Seperti yang sudah berjalan di SMP Tawakkal Denpasar. Sekolah ini memiliki banyak prestasi akademis maupun non akademis meskipun dilihat letak geografisnya berada di daerah pusat pemerintahan juga dekat dengan pusat pembelanjaan serta keramaian lalu lalang kendaraan bermotor, akan tetapi dari aspek pembelajaran memiliki prestasi yang bisa

\footnotetext{
${ }^{2}$ Made Pidarta, Pemikiran tentang Supervisi Pendidikan (Jakarta: Bumi Aksara, 1996), h. 380.

${ }^{3}$ Mushaf Al-Qur'an.Op. Cit. h.828
} 
diandalkan khususnya untuk sekolah yang berbasis Islam terpadu..

SMP Tawakkal Denpasar sebagai lembaga pendidikan formal yang memiliki visi "Membentuk generasi Rabbani yang unggul dan cerdas spiritual, intelektual, emosional, mandiri dan kreatif", menjadikan seluruh komponen sekolah bekerja keras guna terwujudnya visi dengan peran kepala sekolah sebagai penggerak kearah tujuan tersebut.

Problematik sekolah baik secara teknis maupun non teknis dalam proses pembelajaran, masih ada guru yang tidak membuat Rencana Pelaksanaan Pembelajaran (RPP), kurangnya motivasi guru dalam pembelajaran dan masih kurang adanya komunikasi yang baik antara guru dengan murid serta dengan orang tuanya. Hal ini yang mendorong penulis mengadakan penelitian di Sekolah ini. dengan harapan penelitian ini dapat memberikan gambaran yang jelas bagaimana peran supervisi kepala sekolah dalam meningkatkan kinerja guru di SMP Tawakkal Denpasar Tahun Pelajaran 2019/2020..

\section{Pengertian Supervisi}

Secara bahasa, kata "supervisi" berasal dari dua kata, yaitu super dan vision. Dalam Webster's New the World Dictionary istilah "super" berarti higher in rank or position than, superior to (superintendent), a greater or better than others" (peringkat atau posisi yang lebih tinggi, superior, atasan, lebih dekat atau lebih baik). Sedangkan kata "vision" berarti the ability to perceive something not actually visible, as through mental acutness or keen forsight (kemampuan untuk menyadari sesuatu yang tidak benar-benar terlihat). ${ }^{4}$ Berdasarkan gabungan dua unsur pembentuk kata supervisi, dapat disimpulkan bahwa supervisi adalah pandangan dari orang yang lebih ahli kepada orang yang memiliki keahlian di bawahnya. ${ }^{5}$ Ada beberapa tokoh yang mengemukakan pendapat mengenai supervisi:

4 Dalam kamus Webster"s New the World yang dikutip oleh Aguslani dan Rusdi dalam bukunya yang berjudul Supervisi Pendidikan Teori dan Praktik (Bandung: Remaja Rosdakarya, 2018), h. 42

5 Nur Aedi, Pengawasan Pendidikan: Tinjauan Teori dan Praktek (Jakarta: PT Raja Grafindo Persada, 2014), h. 12
1) Piet A. Sahertian, mengemukakan bahwa supervisi adalah sebuah usaha pemberian layanan terhadap guru baik secara individual maupun kelompok dalam mencapai fungsi pengajaran yang efektif dan efisien. ${ }^{6}$

2) Ngalim Purwanto, mengemukakan bahwa supervisi adalah suatu aktivitas pembinaan yang direncanakan untuk membantu para guru dan pegawai sekolah dalam melakukan pekerjaan secara aktif. Ia berupa dorongan, bimbingan, dan kesempatan bagi pertumbuhan keahlian dan kecakapan guruguru, seperti bimbingan dalam usaha dan pelaksanaan pembaharuan-pembaharuan dalam pendidikan dan pengajaran, pemilihan alat-alat pelajaran dan metodemetode mengajar yang lebih baik, cara-cara penilaian yang sistematis terhadap fase seluruh proses pengajaran, dan sebagainya ${ }^{7}$

3) Jasmani dan Syaiful Musthofa, mengemukakan bahwa supervisi adalah segala bantuan dari supervisor atau kepala madrasah untuk memperbaiki manajemen pengelolaan madrasah dan meningkatkan kinerja staf/guru dalam menjalankan tugas, fungsi dan kewajibannya sehingga tujuan pendidikan dapat dicapai dengan optimal ${ }^{8}$

4) Mukhtar dan Iskandar mengemukakan bahwa Supervisi pendidikan adalah suatu usaha mengkooordinasi dan membimbing secara kontinu pertumbuhan guru-guru di sekolah baik secara individu maupun kelompok untuk perbaikan-perbaikan dan pembinaan aspek pengajaran. ${ }^{9}$

Supervisi adalah segala bantuan dari para pemimpin sekolah, yang tertuju kepada perkembangan kepemimpinan guru-guru dan personel sekolah lainnya di dalam mencapai tujuan-tujuan pendidikan. la berupa

${ }^{6}$ Piet A. Sahertian, Konsep dan Teknik Supervisi Pendidikan (Jakarta: Rineka Cipta, 2000), h. 17

${ }^{7}$ Ngalim Purwanto, Administrasi dan
Supervisi $\quad$ Pendidikan (Bandung: Remaja
Rosdakarya, 2009), h. 76
${ }^{8}$ Jasmani Asf dan Syaiful Mustofa,
Supervisi Pendidikan Terobosan Baru dalam
Peningkatan Kinerja Pengawas Sekolah dan Guru,
(Jogjakarta: Ar-Ruzz Media, 2013), h.27
${ }^{9}$ Muhktar dan Iskandar, Orientasi Baru
Supervisi Penedidikan, (Jakarta: Gaung Persada,
2009), h.41


dorongan, bimbingan, dan kesempatan bagi pertumbuhan keahlian dan kecakapan guruguru, seperti bimbingan dalam usaha dan pelaksanaan pembaharuan-pembaharuan dalam pendidikan dan pengajaran, pemilihan alat-alat pelajaran dan metode-metode mengajar yang lebih baik, cara-cara penilaian yang sistematis terhadap fase seluruh proses pengajaran, dan sebagainya. ${ }^{10}$

Dengan kata lain supervisi ialah suatu aktivitas pembinaan yang direncanakan untuk membantu para guru dan pegawai sekolah lainnya dalam melakukan pekerjaan mereka secara efektif. Supervisi merupakan pengawasan terhadap pelaksanaan kegiatan teknis edukatif di sekolah, bukan sekedar pengawasan fisik terhadap fisik material. "Supervisi merupakan pengawasan terhadap kegiatan akademik yang berupa proses belajar mengajar, pengawasan terhadap guru dalam mengajar, pengawasan terhadap situasi yang menyebabkannya." 11 Aktivitas dilakukan dengan mengidentifikasi kelemahankelemahan pembelajaran untuk diperbaiki, apa yang menjadi penyebabnya dan mengapa guru tidak berhasil melaksanakan tugasnya baik. Berdasarkan hal tersebut kemudian diadakan tindak lanjut yang berupa perbaikan dalam bentuk pembinaan.

\section{Macam-macam Supervisi}

1) Supervisi Akademik

Yaitu yang menitik beratkan pengamatan supervisor pada masalahmasalah akademik, yaitu hal-hal yang langsung berada dalam lingkungan kegiatan pembelajaran pada waktu siswa sedang dalam proses pembelajaran.

2) Supervisi Administrasi

Yang menitik beratkan pengamatan supervisor pada aspek-aspek administrasi yang berfungsi sebagai pendukung dengan pelancar terlaksanannya pembelajaran.

3) Supervisi Lembaga.

Yang menitik beratkan pengamatan supervisor pada aspek-aspek yang berada di

10Ngalim Purwanto, Administrasi Dan Supervisi Pendidikan (Bandung: Remaja Rosdakarya, 2010), h.76

11Dadang suhardan, supervisi profesional, (Bandung: Alfabeta, 2010) h. 39 sentral madrasah. Jika supervisi akademik dimaksudkan untuk meningkatkan pembelajaran, maka supervisi lembaga dimaksudkan untuk meningkatkan nama baik madrasah atau kinerja madrasah. ${ }^{12}$

\section{Prinsip-Prinsip Supervisi pendidikan}

1) Prinsip Ilmiah.

Prinsip ilmiah mengandung ciri-ciri sebagai berikut:

a) Kegiatan supervisi dilaksanakan berdasarkan data obyektif yang diperoleh dalam kenyataan pelaksanaan proses belajar mengajar.

b) Untuk memperoleh data perlu diterapkan alat perekam data seperti angket, observasi, percakapan pribadi, dan seterusnya.

c) Setiap kegiatan supervisi dilaksanakan secara sistematis terencana.

2) Prinsip Demokratis

Servis dan bantuan yang diberikan kepada guru berdasarkan hubungan kemanusian yang akrab dan kehangatan sehingga guruguru merasa aman untuk mengembangkan tugasnya. Demokratis mengandung makna menjunjung tinggi harga diri dan martabat guru, bukan berdasarkan atasan dan bawahan.

3) Prinsip Kerjasama

Mengembangkan usaha bersama atau menurut istilah supervisi "sharing of idea, sharing of experience" memberi support mendorong, menstimulasi guru, sehingga mereka merasa tumbuh bersama.

4) Prinsip konstruktif dan kreatif

"Setiap guru akan merasa termotivasi dalam mengembangkan potensi kreativitas kalau supervisi mampu menciptakan suasana kerja yang menyenangkan, bukan melalui cara-cara menakutkan." 13

\section{Prinsip-prinsip berikut:}

a) Supervisi hendaknya bersifat konstruktif dan kreatif, yaitu pada yang dibimbing dan diawasi harus dapat menimbulkan dorongan untuk bekerja.

12Dadang suhardan, supervisi profesional, (Bandung:

Alfabeta,2010), h. 47

13Piet A. Sahertian, Konsep Dasar dan

Tehnik SupervisPendidikan Dalam Rangka Mengembangkan SDM, (Jakarta: Rineka Cipta, 2008), h. 19 
b) Supervisi harus didasarkan atas keadaan dan kenyataan yang sebenarbenarnya ( reslistis, mudah dilaksanakan ).

c) Supervisi harus sederhana dan informal dalam melaksanakannya.

d) Supervisi harus dapat memberikan perasaan aman kepada guru-guru dan pegawaipegawai sekolah yang disupervisi.

e) Supervisi harus didasarkan atas hubungan professional, bukan atas dasar hubungan pribadi.

f) Supervisi harus selalu memperhitungkan kesanggupan, sikap, dan mungkin prasangka guru-guru dan pegawai.

g) Supervisi tidak bersifat mendesak (otoriter) karena dapat menimbulkan perasaaan gelisah atau bahkan antipati dari guru-guru.

h) Supervisi tidak boleh didasarkan atas kekuasaaan pangkat, kedudukan atau kekuasaan pribadi.

i) Supervisi tidak boleh bersifat mencari-cari kesalahan dan kekurangan.

j) Supervisi tidak dapat terlalu cepat mengharapkan hasil, dan tidak boleh lekas merasa kecewa.

k) Supervisi hendaknya juga bersifat preventif, korektif, dan kooperatif. Preventif berarti berusaha mencegah jangan sampai timbul hal-hal yang negatif. Sedangkan korektif yaitu memperbaiki kesalahan-kesalahan yang telah di perbuat. Dan kooperatif berarti bahwa mencari kesalahankesalah atau kekurangan-kekurangan dan usaha memperbaikinya ndilakukan bersama-sama oleh supervisor dan orang-orang yang diawasi. ${ }^{14}$

Menurut Dodd dalam buku Pnduan Supervisi Akademik Dirjen PMPTK (2010) dinyatakan bahwa sejumlah prinsip dalam supervisi akademik meliputi:

1) Praktis: Berkaitan dengan kemudahan dalam melaksanakan kegiatan supervisi sesuai dengan kondisi sekola.

2) Sistematis: Berkaitan dengan perencanaan program supervisi yang matang dan tujuan pembelajaran.

3) Objektif: Berkaitan dengan masukan sesuai aspek-aspek instrumen yang akan digunakan dalam supervisi.

4) Realitis: Berkaitan dengan kenyataan sebenarnya dalam melakukan supervisi.
5) Antisipatif: Berkaitan dengan kemampuan dalam menghadapi masalahmasalah yang mungkin akan terjadi.

6) Konstruktif: Berkaitan dengan pengembangan kreativitas dan inovasi guru dalam mengembangkan proses pembelajaran.

7) Kooperatif: Berkaitan dengan kerja sama yang baik antara supervisor dan guru dalam mengembangkan pembelajaran.

8) Kekeluargaan: Berkaitan dengan pertimbangan saling asah,asih, dan asuh dalam mengembangkan pembelajaran

9) Demokrasi: Berkaitan dengan pemahaman bahwa supervisor tidak boleh mendominasi pelaksanaan supervisi akademik.

10) Aktif: Berkaitan dengan keaktifan guru dan supervisor untuk berpartisipasi

11) Humanis: Berkaitan dengan kemampuan guru menciptakan hubungan kemanusiaan yang harmonis, terbuka,jujur, ajeg, sabar, antusias,dan penuh humor.

12) Berkesinambungan: Berkaitan dengan kesinambungan kegiatan supervisi akademik oleh kepala sekolah

13) Terpadu: Berkaitan dengan kesatuan dengan program pendidikan

14) Komprenhensip: Berkaitan dengan pemenuhan ketiga tujuan supervisi akademik." 15

Supervisi berfungsi membantu, memberi, mengajak. Dilihat dari fungsinya, tampak dengan jelas peranan supervisi itu. Seorang sopervisor dapat berperan sebagai :

1) Koordinator: Sebagai koordinator ia dapat mengkoordinasi program belajar mengajar, tugas-tugas anggota dalam berbagai kegiatan berbeda-beda diantara guru-guru.

2) Konsultan: Sebagai konsultan ia dapat memberi bantuan yaitu bersama mengkonsultasikan masalah yang dialami guru baik secara individual maupun kelompok.

3) Pemimpin Kelompok: Sebagai pemimpin kelompok ia dapat memimpin sejumlah staf guru dalam mengembangklan potensi kelompok pada saat mengembangkan kurikulum, materi pembelajaran dan

\footnotetext{
${ }^{15}$ Donni Juni Priansa Rismi Somad, Manajemen Supervisi dan Kepemimpinan Kepala Sekolah, (Bandung: Alfabeta), h.110
} 
kebutuhan professional guru-guru secara bersama.

4) Evaluator: Sebagai evaluator ia dapat membantu guru-guru dalam menilai hasil dan proses belajar mengajar. ${ }^{16}$

\section{Kinerja Guru}

Istilah kinerja terjemahan dari performance. Karena itu, istilah kinerja juga sarna dengan istilah perfomansi. Selanjutnya.. Simamora menyatakan, "kinerja adalah keadaan atau tingkat perilaku seseorang yang harus dicapai dengan persyaratan tertentu." ${ }^{17}$ Sementara itu, dengan kalimat yang senada, Bernandin dan Russel seperti yang dikutip oleh Gomes, menyatakan "istilah kinerja dengan perfomansi adalah sejumlah catatan yang dihasilkan dari fungsi suatu pekerjaan tertentu atau kegiatan selama suatu periode waktu tertentu."18 "Kinerja merupakan penampilan dan perbuatab seseorang dalam melaksanakan pekerjaan atau tugas." ${ }^{19}$ Tingkat keberhasilan guru dalam menyelesaikan pekerjaannya disebut dengan istilah "level of performance" atau level kinerja.

\section{METODE PENELITIAN}

Berdasarkan pemaparan di atas, penelitian ini menggunakan pendekatan kualitatif karena penulis ingin mengungkap makna yang sebenarnya terhadap semua data yang tampak di lapangan. Karena pada "Hakikatnya, penelitian kualitatif adalah penelitian yang menekankan pada kualitas atau hal yang terpenting dari suatu barang/jasa. Hal yang terpenting dari suatu barang atau jasa berupa kejadian/fenomena/gejala sosial adalah makna dibalik kejadian tersebut yang dapat dijadikan pelajaran berharga bagi suatu pengembangan konsep teori."20

16Op, Cit., Piet A. Sahertian, h. 25

17Henry Simamora, manajemen sumber daya manusia, (Yogyakarta: STIE YKPN,

18Ibid., h. 35

19Muhammad Fathurrohman,

Sukses Menjadi Pengawas Sekolah Ideal, (Yogyakarta: Ar- ruzz media, 2015), h. 151

\footnotetext{
${ }^{20}$ Djam'an Satori dan Aan Komariah, Metodologi Penelitian Kualitatif, (Bandung: Alfabeta, 2014), h. 22
}

Tahap analisis data dalam penelitian ini meliputi tiga kegiatan utama yaitu, reduksi data, penyajian data, penarikan kesimpulan. Reduksi data merupakan kegiatan merangkum, memilih hal-hal yang pokok memfokuskan pada hal-hal yang penting, kemudian dicari tema dan polanya dan membuang yang tidak perlu. Selanjutnya yaitu penyajian data, penulis akan berupaya untuk menyusun data yang relevan dalam bentuk uraian, bagan, atau hubungan antar kategori agar pembaca laporan penelitian akan mengerti proses atau kronologi kegiatan dalam analisis data dan apa yang perlu ditindaklanjuti untuk mencapai tujuan penelitian, sehingga memberi peluang akan adanya penarikan kesimpulan. Dan yang terakhir ialah penarikan kesimpulan. penulis menggunakan strategi yaitu memaknai analisis spesifik dan menarik serta menjelaskan kesimpulan.

\section{HASIL DAN PEMBAHASAN}

Hasil yang didapat berdasarkan data yang diperoleh melalui observasi, wawancara, dan dokumentasi di SMP Tawakkal Denpasar dapat dipaparkan sebagai berikut:

Setelah melakukan penelitian di SMP Tawakkal denpasar mengenai Peran Supervisi Kepala Sekolah dalam meningkatkan Kinerja Guru di SMP Tawakkal Denpasar, didapati hasil bahwa peran Kepala sekolah dalam meningkatkan kinerja Guru telah berjalan cukup baik.

Berdasarkan hasil wawancara wawancara dengan Bapak Fath Jauzi Amry .S.S.Pd.I selaku Kepala Sekolah SMP Tawakkal denpasar mengenai apa yang dimaksud dengan Supervisi Kepala Sekolah adalah "Mengawasi Guru dalam Mengajar, Memberikan Dorongan dan bimbingan keahlian di dalam pembinaan pendidikan dan pengajaran, pemilihan alat alat pelajaran serta metode dalam mengajar."21

\section{Langkah-langkah di dalam Supervisi Guru di SMP Tawakkal Denpasar.}

Menurut bapak Amry selaku Kepala SMP Tawakkal sekolah ialah "kami lakukan

${ }^{21}$ Olah data dan hasil wawancara Fath Jauzi Amry, Kepala Sekolah,, SMP Tawakkal Denpasar Wawancara Pribadi, Denpasar, 1 Juli 2020 
yakni Pemberitahuan terlebih dahulu, Mengatur Jadwal dan pelaksanaannya, lalu kami kami evaluasi dan selanjutnya akan ada tindak lanjutan dari hasil Supervivi" 22

Supervisi yang diterapkan di SMP

Tawakkal menurut Kepala Sekolah Tawakkal Denpasar "Kami menerapkan prinsip ilmiah yaitu dengan cara angket, observasi, dan percakapan pribadi yang di rencanakan, dengan cara demokrasi, menciptakan suasana keakraban menggalang Kerjasama dan menciptakan suasana kerja yang menyenangkan., 23

Jenis-jenis supervise yang dilakukan oleh kepala sekolah Tawakkal Denpasar "Pertama Kami mensupervisi Akademik yakni hal-hal yang berhubungan dengan pembelajaran. Kedua Administrasi yakni sebagai pendukung pelaksanaan pembelajaran. Yang ke tiga Lembaga yakni sebgai aspek yang berada di pusat sekolah agar bisa meningkatkan nama baik sekolah ${ }^{24}$

Ciri-ciri guru yang baik menurut Kepala Sekolah Tawakkal Denpasar adalah "Guru yang baik selalu mempunyai persiapan dalam mengajar mulai dari perencanaan mengajar, menguasai materi, mempunyai metode yang gampang dipahami mempunyai strategi dalam pengeloaan suasana kelas dan mampu memberikan penilaian yang obyektip serta mampu mengevaluasi hasil kinerjanya sendiri. ${ }^{25}$

Seperti yang di contohkan oleh Nabi Muhammad SAW, dalam hadis Shahih Bukhari 5782 Shahih Bukhari 6174 Sunan Tirmidzi.278 tentang sholat bapak Amry juga

${ }^{22}$ Olah data dan hasil wawancara Fath Jauzi Amry, Kepala Sekolah,, SMP Tawakkal Denpasar Wawancara Pribadi, Denpasar, 1 Juli 2020

${ }^{23}$ Olah data dan hasil wawancara Fath Jauzi Amry, Kepala Sekolah,, SMP Tawakkal Denpasar Wawancara Pribadi, Denpasar, 1 Juli 2020

${ }^{24}$ Olah data dan hasil wawancara Fath Jauzi Amry, Kepala Sekolah,, SMP Tawakkal Denpasar Wawancara Pribadi, Denpasar, 1 Juli 2020

${ }^{25}$ Olah data dan hasil wawancara Fath Jauzi Amry, Kepala Sekolah,, SMP TAWAKKAL Denpasar Wawancara Pribadi, Denpasar, 1 Juli 2020 mengecek sholatnya anak didik melalui CCTV yang ada di meja beliau, sehingga dengan mudah bisa mengetahui gerakan sholat anak didknya, yang tidak sesuai dengan ajaran nabi gerakan dalam sholatnya maka anak didik tesebut harus mengulang sampai benar. Khusus bagi guru Penddidkan Agama Islam dan setoran hafalan mendapat perhatian lebih dari kepala sekolah, karena harus sesuai dengan sumbernya yaitu Al-quran dan Hadis Nabi Muhammaat SWT.

\section{Hambatan}

Hambatan dalam pelaksanaan supervisi dilapangan adalah:

1). Kemampuan Sumber Daya Manusia (SDM) guru senior yang tidak bisa di upgrade cepat terutama pada bidang Teknologi Informasi (IT).

2) Rendahnya kesungguhan untuk mengabgrade diri dan membuka wawasan

3) Sarana prasana yang masih terbatas

4) Kemampuan untuk menggunakan sarana prasarana yang modern /berbasis IT. ${ }^{26}$

Dari hasil wawancawa dengan ibu Astrid Heirera Nursyah Bani hamtan wsli kelas 9.2:

1) imbalan yang tidak sesuai

2) mata pelajaran tidak sesuai dengan

3) hubungan antar pribadi

4) kondisi lingkungan kerja

5) kesempatan berkarir

5) kemampuan dan motivasi kerja." 27

Dari hasil penilain supervisi kinerja guru maka seorang kepala sekolah harus mengetahui kekurangan dan kelebihan guru yang ada di bawah kepimpinannya, sehingga kepala sekolah lebih mudah memberi briefing/pengarahan dan bimbingan serta motivasi dalam 1 (satu) minggu minimal 1 kali. Sedangkan setoran ayat (hafalan $\mathrm{Al}$ qur'an setiap pagi, untuk guru minimal harus hafal juz 30, sedangkan bagi siswa SMP Tawakkal hafal juz 30 adalah syarat untuk mengambil ijazah kelulusannya.

Hasil wawancara dengan bapak Basori , S.Pd.I. sekalu wali kelas dan guru mata

${ }^{26}$ Olah data dan hasil wawancara Fath Jauzi Amry, Kepala Sekolah,, SMP TAWAKKAL Denpasar Wawancara Pribadi, Denpasar, 1 Juli 2020

27 Olah data dan hasil wawancara Astrid heirera NB, guru Bahasa Indonesia, SMP TAWAKKAL Denpasar Wawancara Pribadi, Denpasar, 9 Juli 2020 
pelajaran Pendidikan Agama Islam dan AlQur'an bahwa "Yayasan Tawakkal akan memberi apresiasi apabilah ada guru atau staf yang berprestasi akan mendapatkan reword berupa uang tunai atau hand phone dan bagi yang selalu melanggar aturan/tatatertib akan di beri sanksi dan pembinaan khusus oleh kepala sekolah.". 28

Pembinaan khusus disini adalah:

"Bila guru yang melanggar maka akan di beri tugas setor hafalan Bila anak didik yang malanggar akan di beri hukuman membersihan kelas atau mengerjakan sholat di ulang beberapa kali apabila dalam mengerjakan sholat masih bercanda aatau main-main." 29

Menurut ibu Astrid Heirera Nursyah Bani selaku wali kelas 9.2 dan guru Bahasa Indonesia "kurang semangatnya guru dalam mengajar karena beberapa factor antara lain: Waktu di sekolah tidak efektif seharusnya penuh dengan tugas mengajar, guru kurang memahami peraturan sekolah sehingga sering melanggar tanpa ada sangksi seharusnya ada sanksi yang tegas dari sekolah atau Yayasan, memperketatat syarat administrasi sehingga tumbuh rasa untuk memenuhi kewajibannya sebagai guru/.",30

Dari hasil penelitian yang dilakuakan penulis di SMP Tawakkal Denpasar maka menurut menulis hambatan yang paling berat adalah adanya suasana yang berbeda antara ada kepala sekolah dengan tidak adanya kepala sekolah di tempat.namun dari hasil wawan cara dengan bapak Fath Jauzi Amry selaku kepala sekolah Tawakkal denpasar beliau memiliki solosin yang luar biasa yaitu dengan mengangat salah seorang guru yang dirahasiakan orangnya untuk melaporkan semua kejadian selama kepala

${ }^{28}$ Olah data hasil wawancara Basori, wali kelas 8.3, SMP Tawakkal Denpasar Wawancara Pribadi, Denpasar, 9 Juli 2020

$$
30 \text { Astrid heirera NB, guru Bahasa }
$$
Indonesia, SMP TAWAKKAL Denpasar Wawancara Pribadi, Denpasar, 9 Juli 2020 sekolah tidak ada di tempat. Laporan dapat berupa foto dan video.

Selain guru juga ada beberapa siswa kepercayaan yang di beri tugas melaporkan semua kejadian baik diluar kelas maupun di dalam kelas sehingga semua kejadian dapat diketahui walapun kepala sekolah tidak ada di tempat.

\section{PENUTUP}

Berdasarkan kajian teoritis dan pemaparan hasil penelitian yang telah penulis lakukan dapat disimpulkan bahwa Peran Kepala Sekolah dalam Meningkatkan Kinerja guru di SMP Tawakkal Denpsar tahun pelajaran 2019/2020 maka penulis dapat memberi kesimpulan

1. Kinerja guru di SMP Tawakkal Denpasar sangat dirpengaruhi oleh supervisi kepala sekolah jadi semakin baik supervisi kepala sekolah maka akan semakin baik kinerja gurunya.

2. Hambatan bagi kepala sekolah dalam melaksanakan supervisi adalah adanya guru yang tidak memiliki kemampuan, sumber daya manusia yang memadai, rendanya kesungguan guru untuk mengabgrade diri dan membuka wawasan, sarana prasarana yg tidak lengkap

Dalam kesempatan ini, penulis ingin memberikan saran yang bersifat membangun untuk:

1. Bagi Kepala Sekolah diharapkan tetap memelihara hubungan yang baik dengan guru-guru. Melakukan pengawasan secara mendadak (sidak) sehingga tahu kesiapan para guru dalam melaksanakan tugas pembelajaran. Mengawasi guru dalam melaksanakan proses belajar mengajar di dalam kelas. Membimbing secara langsung dalam memecahkan masalah guru yang ada kaitannya dengan tugas dalam melaksanakan kegiatan belajar mengajar.

2. Bagi Guru Terlibat aktif dalam rapat atau pertemuan-pertemuan yang di adakan oleh sekolah, agar tidak terjadi salah pemahaman antara guru dengan kepala sekolah. Mau menerima saran dan kritikan yang membangun dari kepala sekolah. Memperdalam pengetahuan yang dimiliki dengan studi 
lanjut atau mengikuti seminar-seminar agar dapat memperkaya dan menambah wawasan untuk kemajuan kompetensinya.

3. Bagi Peneliti lain Hendaknya penelitian ini dapat menjadi bahan rujukan dalam melakukan penelitian yang sama atau yang sejenis

\section{DAFTAR RUJUKAN}

Al-Qur'an Standar Usmani Departemen Agama RI, (Jakarta: Lautan lestari, $2010\}$

Abdullāh Muḥammad Abū ibn Ismā‘īl ibn Ibrāhīm ibn al-Mughīrah ibn Bardizbah al-Ju'fī, 2010 al-Bukhārī, Shahih Bukhari, Beirut: Insan Kamil.

Aedi Nur, 2014, Pengawasan Pendidikan: Tinjauan Teori dan Praktek Jakarta: PT Raja Grafindo Persada.

Aguslani dan Rudi, 2018, Supervisi Pendidikan Teori dan Praktik, Bandung: Remaja Rodakarya.

Ametembun N.A., 2007. Supervisi Pendidikan Disusun Secara Berprogam. Bandung: Suri

A. Piet Sahertian, 2000, Konsep dan Teknik Supervisi Pendidikan. Jakarta: Rineka Cipta.

Arikunto Suharsimi, 2006, Prosedur Penelitian : Suatu Pendekatan Praktek, Jakarta: PT Rineka Cipta.

Asf Jasmani dan Syaiful Mustofa, 2013, Supervisi Pendidikan Terobosan Baru dalam Peningkatan Kinerja Pengawas Sekolah dan Guru, Jogjakarta: Ar-Ruzz Media.

Bahri Syaiful Djamarah, 2010, Guru dan Anak Didik Dalam Interaksi Edukatif, Jakarta:Pt RinekaCipta

Bungin Burhan,2010, Metode ' Kualitatif, Jakarta:Rajawali Pres.
Depdikbud, 2003, Kamus Besar Bahasa Indonesia, (edisi ke-3, Balai Pustaka, Jakarta.

Etek Yurnalis, 2008, Supervisi Akademik Dan Evaluasi Pengajaran, Jakarta: Transmisi Media,

Imron Ali, 2012. Supervisi Pembelajaran Tingkat Satuan Pendidikan. Jakarta: PT. Bumi Aksara.

Fathurrohman Muhammad, 2015, Sukses Menjadi Pengawas Sekolah Ideal, Yogyakarta: Ar- ruzz media.

Hamalik, 2003, Hasil Lokakarya Pembinaan Kurikulum Pendidikan Guru UPI , Bandung.

Juni Donni Priansa Rismi Somad, Manajemen Supervisi dan pemimpinan Kepala Sekolah. Bandung : Alfabeta.

Margono, 2000, Metodelogi Peneitian Pendidikan, (Jakarta: Rineka Cipta.

Mathis dan Jackson, 2001, Manajemen Sumber Daya Manusia, Jakarta: Buku ke 2,

Mohammad, 2004, Psikologi Pembelajaran dan Pengajaran, Bandung: Pustaka Bani Quraisy

Muhktar dan Iskandar, 2009, Orientasi Baru Supervisi Penedidikan, Jakarta: Gaung Persada.

Mulyasa, E. 2007, Manajeman Berbasis Sekolah, Bandung: PT. Remaja Rosdakarya, 2007, Menjadi Kepala Sekolah Professional, Bandung: PT. remaja Rosdakarya.

Nasution,199, Metode Research, Bandung: Jemmars

Nur Sunarti, 2011, Metode Penelitian Suatu Pendekatan Proposal, Jakarta: Bumi Aksara. 
Pidarta Made, 1996. Pemikiran tentang Supervisi Pendidikan. Jakarta: Bumi Aksara.

Purwanto Ngalim, 2010. Administrasi Dan Supervisi Pendidikan. Bandung: Remaja Rosdakarya.

Ridwan,2010, Belajar Mudah Penelitian untuk Guru, Karyawan, dan Penelitian Pemula, Bandung: Alfabeta.

Sahertian Piet, 2008. Konsep Dasar \& Teknik Supervisi Pendidikan. Jakarta : Rineka Cipta

Satori Djam'an dan Aan Komariah,2014. Metodologi Penelitian Kualitatif Bandung: Alfabeta.

Simamora Henry, 2000, manajemen sumber daya manusia, Yogyakarta: STIE YKPN.

Sudjana Nana Abrahim,1989, Penelitian dan Penilaian Pendidikan, Bandung: Sinar Baru.

Sudiyono Anas, 1987, Statistik Pendidikan, Jakarta: Rajawali Pers.

Suhardan Dadang, 2010. supervisi profesional. Bandung : Alfabeta.

Sugeng, 2016. Implementasi Manajemen Sarana dan Prasarana dalam Peningkatan Mutu Pendidikan di MTs Negeri Sragen, Skripsi. Denpasar: Perpustakaan STAI Denpasar.

Sugiyono 2005, Statistika Untuk Penelitian, Bandung: Alfabeta.

, 2008, Metode Penelitian Kuantitatif, Kualitatif Dan $R \quad \& \quad D$, Bandung: Alfabeta.

, 2014, Metode Penelitian Pendidikan Pendekatan Kuantitatif, Kualitatif, dan $R \& D$, Bandung: Alfabeta.

Sukardi, 2006, Penelitian Kualitatif Naturalistik dalam Pendidikan, Yogyakarta: Usaha Keluarga.
Sulistyorini, 2001, Hubungan Antara Keterampilan Manajerial Kepala Sekolah Dan Iklim Organisasi Dengan Kinerja Guru, Jakarta: Ilmu Pendidikan.

Uzer Moh Usman, 2003, Menjadi Guru Profesional, Bandung: PT . Remaja Rosda Karya.

Wahab Abd dan Umiarso, 2010, Kepemimpinan Pendidikan dan Kecerdasan Spiritual, Jogjakarta: Ar Ruzz Media.

Widodo, 2017, Metodologi Penelitian Populer \& Praktis, Jakarta: Rajawali Press. 